\title{
Properties of a Wine Yeast Antagonist, Saccharomyces cerevisiae T206. A Review
}

\author{
A.S. Vadasz ${ }^{1}$, D.B. Franken ${ }^{1}$, B.L. Govender ${ }^{1}$, D.B. Jagganath ${ }^{1}$, P. Govender ${ }^{1}$, M. Ariatti ${ }^{1}$, I.S. Pretorius ${ }^{2}$ and \\ A.S. Gupthar ${ }^{1}$ \\ 1) Department of Biochemistry, University of Durban-Westville, Private Bag X54001, 4000 Durban, South Africa \\ 2) Institute for Wine Biotechnology, Department of Viticulture \& Oenology, Stellenbosch University, Private Bag X1, 7602 Matieland \\ (Stellenbosch), South Africa
}

Submitted for publication: November 2001

Accepted for publication: June 2002

Key words: $\mathrm{K}_{2}$ killer yeast, Saccharomyces cerevisiae, stuck/sluggish fermentation, wine yeast antagonist, zymocin

\begin{abstract}
Regardless of the type of killer yeast, winemaking may be adversely affected by a single type of killer yeast. In this review we present the properties of a single $K_{2}$ strain, Saccharomyces cerevisiae $\mathbf{T} 206$, which was isolated from a stuck fermentation in a South African winery. This zymotidal strain has demonstrated its potential as a wine yeast antagonist and may be differentiated from other NCYC killer strains of S. cerevisiae on the basis of CHEF karyotyping and mycoviral RNA separations. Resolution of its genomic DNA into 13 chromosome bands, ranging from 0.2 to $2.2 \mathrm{Mb}$, has been reported. The resident viral-like particle in strain T206 yields pancreatic RNase-sensitive $L$ and $M$ double-stranded RNA species of 5.1 and $2.0 \mathrm{~kb}$, respectively. The latter can be cured using cycloheximide to produce a $K^{-} R^{-}$derivative. In microscale vinifications the $K_{2}$ toxin of strain $T 206$ demonstrates a lethal effect on sensitive mesophilic wine yeasts over a narrow pH range of 3.2 to 3.5, disrupting the cell wall structure and perturbing cytoplasmic membranes. Contrary to known fermentation trends, the challenged fermentations are neither stuck nor protracted as strain T206 competes for substrates and induces over $65 \%$ cell death in enriched Hanepoot grape juice media. Mucoid secretions of mesophilic wine yeasts, induced by nutrient limitation, appear to restrict the $K_{2}$ killer effect. However, the supplementation of 1 to $100 \mathrm{ppm}$ bovine submaxillary gland mucin in nutrientenriched grape juice media also depresses the $K_{2}$ killêr effect of strain $T 206$ in mesophilic wine yeast starter culture strain, S. cerevisiae VIN7. Preliminary results suggest that mucoid secretions either affect the level of toxin production by strain $T 206$ or block the cognate $K_{2}$ receptor on the cell wall of challanged yeasts.
\end{abstract}

\section{INTRODUCTION}

Killer (zymocidal) strains of Saccharomyces cerevisiae are commonly encountered in winery ecosystems (Starmer et al., 1987; Van Vuuren \& Jacobs, 1992). Such $\mathrm{K}^{+} \mathrm{R}^{+}$yeasts are known to secrete a proteinaceous mycoviral toxin (killer toxin or zymocin) which is lethal to $\mathrm{K}^{-} \mathrm{R}^{-}$sensitive strains of the same species (Heard \& Fleet, 1987; Starmer et al., 1987; Bussey, 1991). The so-called neutral stains $\left(\mathrm{K}^{-} \mathrm{R}^{+}\right)$do not secrete any killer toxin, but they are resistant to the zymocins of other $S$. cerevisiae strains (Wingfield et al., 1990). Based on the properties of the toxin, killer yeasts have been classified into at least 11 groups $\left(\mathrm{K}_{1}-\mathrm{K}_{11}\right)$, five of which $\left(\mathrm{K}_{1}, \mathrm{~K}_{2}, \mathrm{~K}_{3}, \mathrm{~K}_{28}\right.$ and $\left.\mathrm{K}_{3} \mathrm{GR} 1\right)$ are specific to $S$. cerevisiae (Young \& Yagiu, 1978; Extremera et al., 1982; Pfeiffer \& Radler, 1982). Killer yeasts are generally immune to their own toxin; however, since wine fermentations are conducted within a nonsterile grape must environment, there exists the potential for ubiquitous wild killer yeasts to interfere with the fermentation. The enological importance of detecting killer yeasts, regardless of the genus or species to which they belong, relates to their potential ability to dominate natural, spontaneous wine fermentations or those wine fermentations initially inoculated with a sensitive wine yeast. In either scenario the domination of the fermentation by the killer strain has been reported to delay the onset of the fer- mentation and cause sluggish or "stuck" fermentations (Van Vuuren \& Wingfield, 1986; Radler \& Knoll, 1988; Longo et al., 1990; Carrau et al., 1993), thereby contributing to a lower turnover of tankage (Jacobs \& Van Vuuren, 1991). Killer-straindominated fermentations have also been reported to give wines an unfavourable organoleptic profile, evident in high volatile acidity, $\mathrm{H}_{2} \mathrm{~S}$ production and off-flavours caused by fusel oils, acetaldehyde and lactate as well as reduced ethanol yields. These factors can result in serious financial losses to the wine industry (Benda, 1985; Van Vuuren \& Jacobs, 1992).

Van Vuuren \& Wingfield (1986) first described stuck or protracted fermentations in a South African wine cellar which were induced by the $\mathrm{K}_{2}$ killer yeast, $S$. cerevisiae T206. Noting that considerable heterogenecity existed among killer yeasts with respect to their ability to kill different sensitive strains (Jacobs \& Van Vuuren, 1991), Franken et al. (1998) re-investigated the killer property of strain T206 using a sensitive mesophilic wine yeast in a simulated challenge experiment. Contrary to known fermentation trends (Van Vuuren \& Wingfield, 1986; Longo et al., 1990; Carrau et al., 1993), the challenged fermentations were neither stuck nor protracted, although over $70 \%$ of the mixed cell population was killed in 72 hours.

In this article we present the fermentation properties of $S$. cere- 
visiae T206 in microscale vinifications using enriched and dilute Hanepoot grape juice samples. Emphasis is given to simulated challenges involving strain T206 and mesophilic wine yeasts using both enriched and nutrient-depleted media. Characteristics of the $\mathrm{K}_{2}$ killer effect are reported using electron microscopy. In addition, the differentiation of $S$. cerevisiae T206 from other yeasts on the basis of nucleic acid constitution is also presented. Previous reviews on killer yeasts (Bussey, 1991; Jacobs \& Van Vuuren, 1991) concentrated on the $K_{1}$ killer strain of S.cerevisiae, which appeared to be the dominant spoilage yeast in certain wineries. Given the equal potential that $\mathrm{K}_{2}$ killer strains may also interfere with the winemaking process, we find it pertinent to present in this review the properties of such a yeast in comparison with those of other types. In addition, this review is the first to collate the properties of a South African $\mathrm{K}_{2}$ killer strain of $S$. cerevisiae.

\section{NUCLEIC ACID CONSTITUTION AND STRAIN DIFFERENTIATION}

\section{Chromosomes}

Electrophoretic karyotyping may be used circumspectly in "fingerprinting" S. cerevisiae strains as some of them tend to show dynamic changes in chromosome number and size owing to meiotic recombination (Bidenne et al., 1992; Longo \& Vezinhet, 1993) or segregation of "plasmid minichromosomes" from intact chromosomes (Kaback, 1989). Franken et al. (1998) presented the chromosome banding pattern of strain T206 using a combination of the embedded-agarose procedure of Carle \& Olsen (1985) and the CHEF technique (Van der Westhuizen \& Pretorius, 1992). The genomic DNA of strain T206 was resolved into 13 chromosome bands, ranging from approximately 0.2 to $2.2 \mathrm{Mb}$, the smallest and largest chromosomes corresponding to marker chromosomes I and XII of S. cerevisiae strain YNN 295 (Fig. 1). Strain T206 could be differentiated from the wine yeast, S. cerevisiae CSIR Y217; on the basis of doublet bands corresponding to the 0.58 and $0.46 \mathrm{Mb}$ markers of strain YNN 295 (Fig. 1, lanes 1 and 2). Strain Y217 produced only a single chromosome band in the $0.46 \mathrm{Mb}$ position (Fig. 1, lane 5). Strain T206 could also be differentiated from the $\mathrm{K}_{2}$ killer $S$. cerevisiae NCYC 738 and the $\mathrm{K}_{1}$ killer yeast, $S$. cerevisiae NCYC 190 on the basis of electrophoretic karyotypes (Fig. 1, lanes 2-4).

\section{Mycoviral RNA}

$\mathrm{K}_{2}$ killer strains of $S$. cerevisiae are known to harbour virus-like particles (VLPs) which contain two major types of double-stranded ribonucleic acid (dsRNA), designated the $\mathrm{L}$ and $\mathrm{M}$ species (Bostian \& Tipper, 1984). The LdsRNA genome codes for an RNA-dependent RNA polymerase and capsid protein for both genomes, whereas the MdsRNA generally encodes the proteinaceous killer toxin and immunity against this compound. In S. cerevisiae T206 VLPs of a hexagonal structure of approximately 30$40 \mathrm{~nm}$ have been isolated and viewed by transmission electron microscopy (TEM) and the double-stranded L and M mycoviral RNA species were estimated to be 5.1 and $1.5 \mathrm{~kb}$, respectively (Van Vuuren \& Wingfield, 1986). Franken et al. (1998) reported that the size of the LdsRNA genome was found to be reproducible and stable at $5.1 \mathrm{~kb}$. However, the M species of RNA was found to be approximately $2.0 \mathrm{~kb}, 33 \%$ larger than originally reported. The RNA genomes of the $\mathrm{K}_{2}$ killer, $S$. cerevisiae NCYC 738, and $\mathrm{K}_{1}$ killer, S. cerevisiae NCYC 190, were found to be similar in size to those of strain T206 (Fig. 2). In that study all RNA species, including a high concentration of low molecular species $(<0.83 \mathrm{~kb})$, were found to be susceptible to pancreatic RNase digestion but resistant to DNase I action as expected (Fig. 2). Size variation of the MdsRNA genome is known to occur in $S$. cerevisiae diploids when $K_{1}$ killer strains possessing the $M_{1}$ genomic species of ca. $1.8 \mathrm{~kb}$ are mated with $\mathrm{K}_{2}$ killer cells containing the $\mathrm{M}_{2}$ RNA genome of $1.5 \mathrm{~kb}$. The heterozygous diploids lose the $\mathrm{M}_{2}$ genome and retain the larger $\mathrm{M}_{1}$ species, which appears to compete more effectively for replication factors (Sommer \& Wickner, 1984). Other mechanisms which could contribute to size variation in MdsRNA genomes include the duplication of genes due to polymerase errors and the incorporation of foreign sequences during replication (Sommer \& Wickner, 1984; Wingfield et al., 1990).

Cycloheximide curing of strain T206 yields a $\mathrm{K}^{-} \mathrm{R}^{+}$trait when testing the derivative against its killer progenitor T206 on methylene blue-yeast extract agar, buffered with citric phosphate (Heard

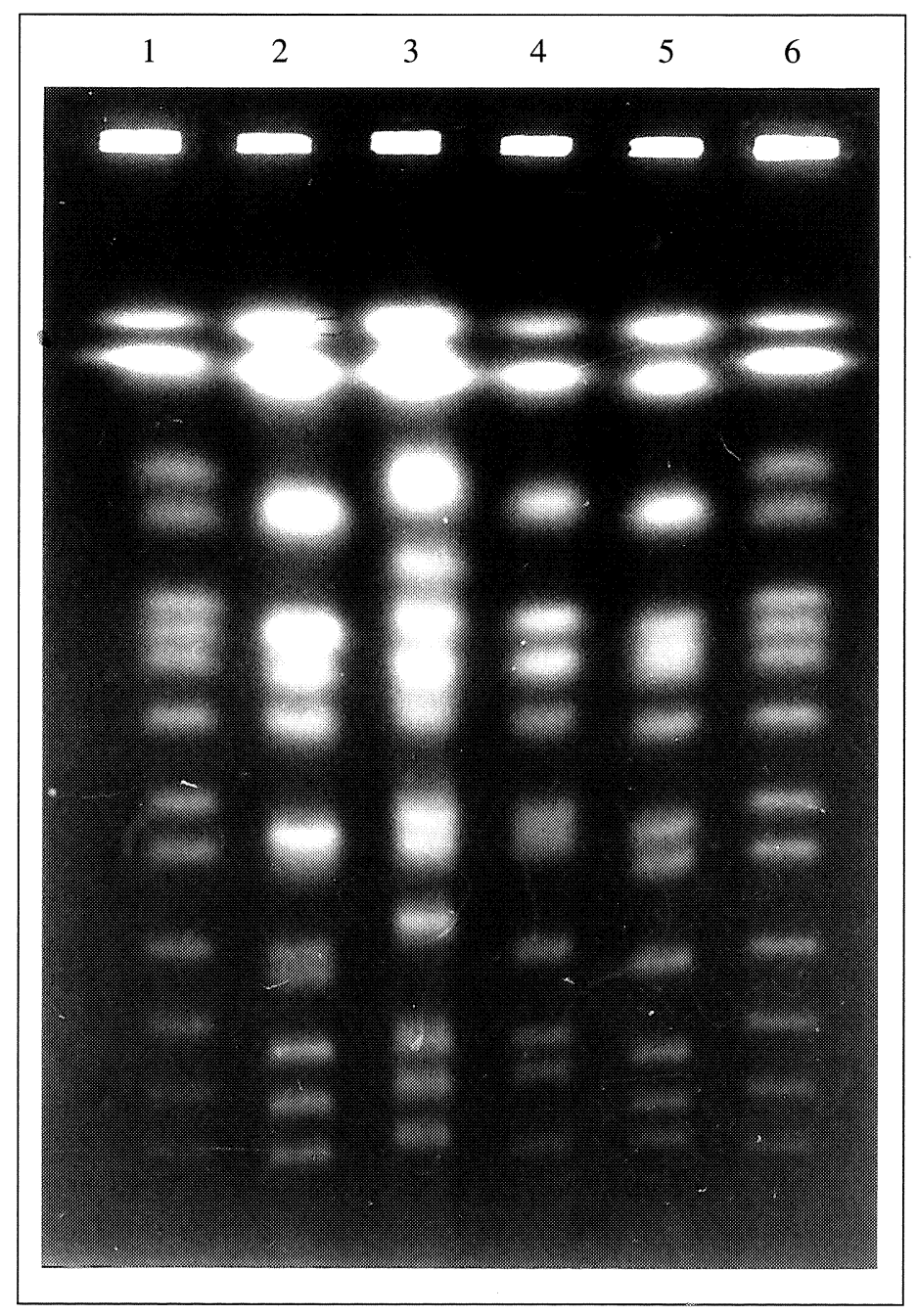

\section{FIGURE 1}

Electroforetic karyotyping of killer yeast strains. Contour clamped homogenous electric field (CHEF) banding patterns of chromosomal DNA of $S$. cerevisiae strains: Lane 1, YNN 295 (marker); lane 2, T206; lane 3, NCYC 738; lane 4, NCYC 190; lane 5, CSIR Y217; and lane 6, marker strain (repeated) (Franken et al., 1998). 
\& Fleet, 1987). A lawn of the cured derivative did not yield a ring of darkly stained dead cells or a zone of growth inhibition (Fig. 3b) when challenged on this medium by streaks of T206 $\mathrm{K}^{+} \mathrm{R}^{+}$(Fig. 3a). The $\mathrm{K}^{-}$trait of the derivative, against $\mathrm{K}^{-} \mathrm{R}^{-}$ mesophilic wine yeasts, was confirmed using the same medium (data not shown). Neutral $\mathrm{K}_{2}$ strains of $S$. cerevisiae, which are cured of the MdsRNA genome, are expected to be non-producers of the viral toxin and generally sensitive to it. Indeed, this is valid if the MdsRNA genome encoded both the toxin and immunity against it, as documented in the literature (Wingfield et al., 1990). Curing of the MdsRNA genome in strain T206 manifests in a $\mathrm{K}^{-}$ $\mathrm{R}^{+}$trait, suggesting that the immunity against the toxin may not be entirely cytoplasmically encoded. The origin of resistance in this derivative against its killer progenitor has yet to be investigated.

\section{$\mathrm{K}_{2}$ TOXIN ACTIVITY AND CELL DAMAGE}

\section{Properties and activity of the $K_{2}$ toxin}

Very little is currently known about the chemical composition of the $\mathrm{K}_{2}$ toxin of strain T206. A comparison of protein profiles of the killer strain with those of the killer-cured derivative revealed a protein band of approximately $20 \mathrm{kD}$, believed to be the putative killer toxin (Wingfield et al., 1990). In microscale vinifications Franken et al. (1998) demonstrated toxin activity in a narrow $\mathrm{pH}$ range of 3.2 to 3.5 at $25^{\circ} \mathrm{C}$ when $S$. cerevisiae CSIR Y217 $\mathrm{K} \cdot \mathrm{R}$-, a mesophilic wine yeast, was challenged by strain T206 in the early logarithmic phase of growth at a killer:sensitive $(\mathrm{k} / \mathrm{s})$ cell ratio of 1:100. The minimum variation in $\mathrm{pH}$ during $96 \mathrm{~h}$ of fermentation was attributed to the buffer capacity of $\left(\mathrm{NH}_{4}\right)_{2} \mathrm{HPO}_{4}$ used to enrich a Hanepoot grape juice medium with nitrogen. Other researchers found the $\mathrm{K}_{2}$ killer toxin to be stable over a wide $\mathrm{pH}$ range of 2.8 to 4.8 (Rogers \& Bevan, 1978) and the optimum $\mathrm{pH}$ for killer activity was reported to be between 4.2 and 4.4 (Pfeiffer \& Radler, 1984).

These are reasons to believe that the extent of killing in a challenge experiment involving killer and sensitive yeasts might be influenced by the ratio of the different cells. Heard \& Fleet (1987) studied the incidence of killer yeasts in Australian wineries and found that the killer effect was not apparent when the ratio of

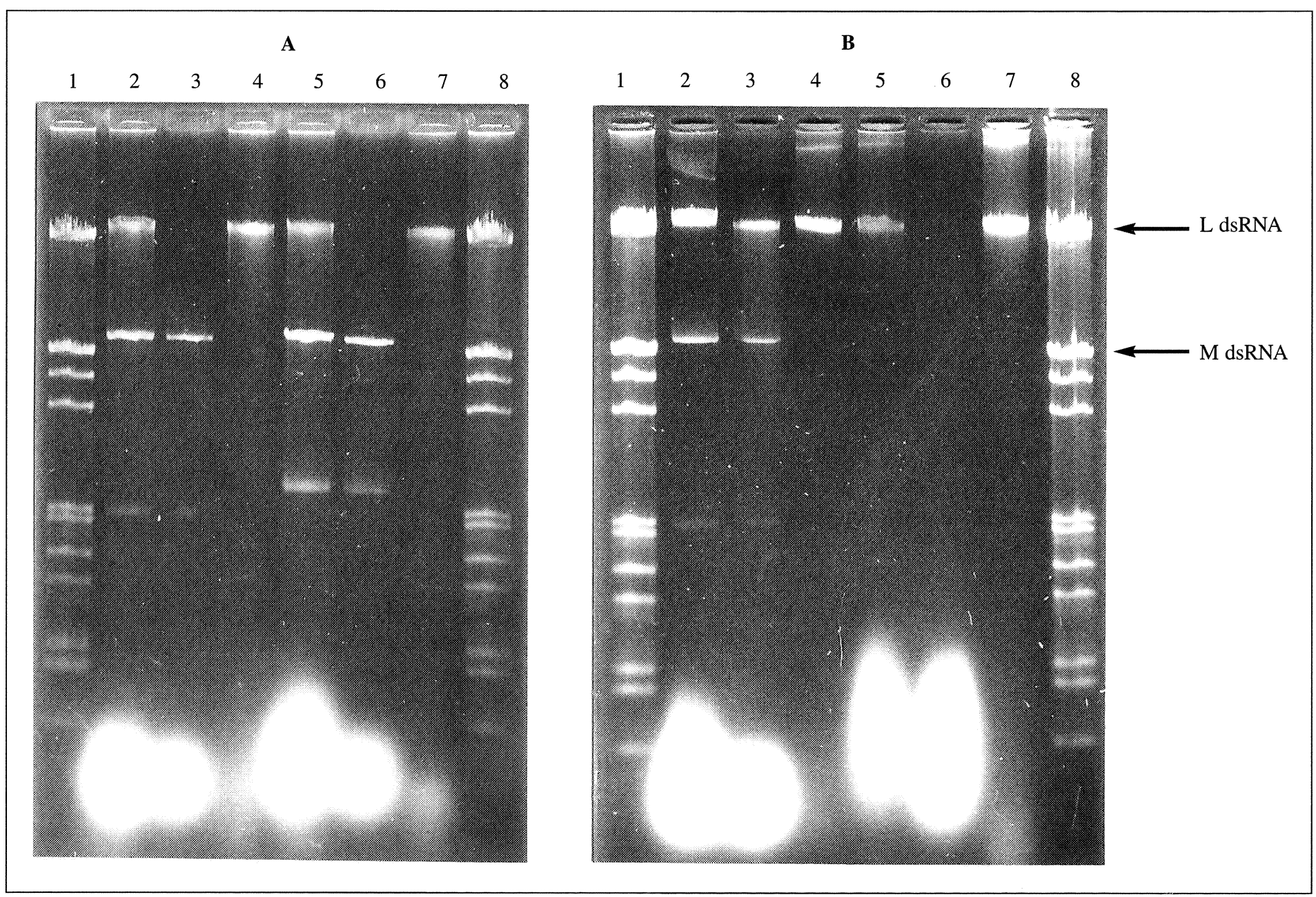

FIGURE 2

Agarose gel (1\%) of L and M mycoviral RNA from killer yeasts. (A): Lanes 1 and 8, DNA marker III (EcoRI-HindIII digest of $\lambda$ DNA) (Boehringer Mannheim, FRG); lanes 2-4, RNA of strain NCYC 738 undigested, DNase I and RNase-digested, respectively; lanes 5-7, RNA of strain NCYC 190 undigested, DNase 1 and RNase-digested, respectively. (B): Lanes 1 and 8, DNA marker III; lanes 2-4, RNA of strain T206 undigested, DNase I and RNase-digested, respectively; lanes 5-7, RNA of strain CSIR Y217K-R- undigested, DNase I and RNase digestion, respectively (Franken et al., 1998). 
A

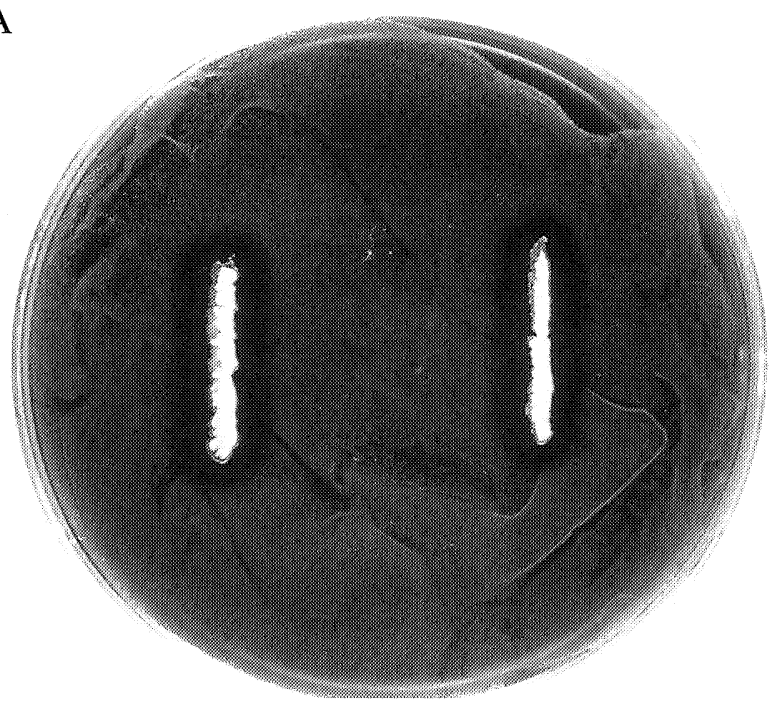

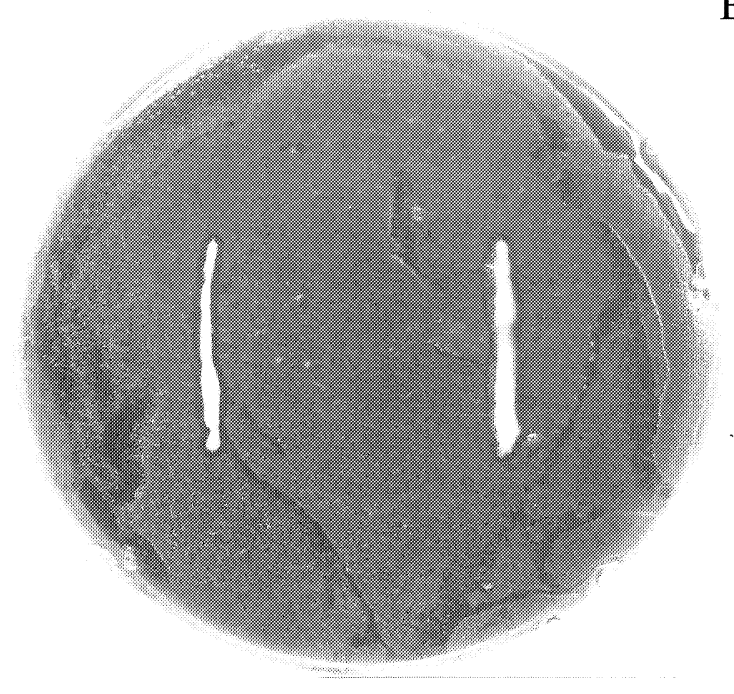

FIGURE 3

Methylene blue agar plate assays of killer activities. (A) The killer activity of strain T206 $K^{+} R^{+}$demonstrated by a zone of clearing and ring of darkly stained dead cells of $S$. cerevisiae Y217 K-R. (B): Resistance against the $\mathrm{K}_{2}$ killer effect of strain T206 $\mathrm{K}^{+} \mathrm{R}^{+}$by its derivative, S. cerevisiae $\mathrm{T} 206 \mathrm{~K} \cdot \mathrm{R}^{+}$(Vadasz, 2000a).

killer to sensitive cells ( $\mathrm{k} / \mathrm{s}$ ratio) at the commencement of the fermentation was as high as 1:7. However, pronounced killer activity was reported when the $\mathrm{k} / \mathrm{s}$ ratio was approximately $1: 1$. Carrau et al. (1993) recorded $82 \%$ cell death when a $\mathrm{k} / \mathrm{s}$ ratio of $1: 100$ was used during inoculation. In contrast, they also reported cell death of 22 and $21 \%$ when $\mathrm{k} / \mathrm{s}$ ratios of $1: 1$ and $1: 10000$ were employed, respectively.

\section{Cell damage}

The nature of cell damage, induced by the $\mathrm{K}_{2}$ killer toxin of strain T206, was evaluated by scanning (SEM) and transmission (TEM) electron miscroscopy (Franken et al., 1998; Vadasz et al., 2000a). Mesophilic wine yeasts, such as S. cerevisiae CSIR Y217 and VIN7, which were challenged by strain T206 in grape juice fermentations, showed rippled cell surfaces, characterised by "cracks" and pores (Figs. 4a, b and c). It is generally accepted that cytosolic efflux and cell death is the result of the initial interaction of yeast killer toxins to specific cell wall receptors (Hutchins \& Bussey, 1983; Bussey, 1991), followed by the formation (Martinac et al., 1990) or activation of endogenous ion channels in the plasma membrane of target cells (Ahmed et al., 1999). One such example of the latter is the potassium selective ion channel, TOK1, which is expressed in the plasma membrane of $S$. cerevisiae strains. While the plasma membrane of target cells is implicated in cytosolic efflux, there is little information concerning the structural integrity of the cell wall and that of cytoplasmic membranes (Fig. 5a) in the event of a killer yeast challenge (Fig. 5b). Vadasz et al. (2000a) concluded from their studies that the $\mathrm{K}_{2}$ toxin of $S$. cerevisiae T206 could involve interaction with a specific cell wall receptor, followed by its ability to disrupt cell wall structure (Fig. 5d) and perturb cytosolic membranes (Fig. 5b). In that study toxin-damaged cells showed a crenulated plasma membrane, generating "pinocytotic"-type vesicles (Fig. 5c) or endosomes possibly associated with the internalisation of toxin-receptor complexes (Figs. 6a and b). However, they also speculated that plasma membrane-associated vesicles may originate from golgi cisternae and these could be linked to the exocytosis of secretory compounds to the periplasmic space. A lobular nucleus and poorly defined mitochondrial cristae were amongst other features reported in the toxin-challenged cells (Fig. 5). The findings presented by Vadasz et al. (2000a) indicate that the ruptured cell wall provided the efflux outlet, consequently leading to the loss of turgidity (Fig. 4a) and the retraction of an intact plasma membrane from the periplasmic space, coupled with irregular folding (Fig. 5c). The possible activation of specific plasma membrane ion channels by the $\mathrm{K}_{2}$ toxin of $S$. cerevisiae T206 remains to be investigated.

\section{MICROSCALE VINIFICATIONS AND THE $\mathrm{K}_{2}$ KILLER EFFECT}

It is true that certain stuck or protracted wine fermentations have been influenced by different killer yeasts. Besides the killer yeast, it is also known that such fermentations may be influenced by a variety of factors such as oxygen levels, grape solids and nutrient content, as well as fermentation temperatures, toxic compounds, the wine yeast strain, grape varieties and growth conditions in vineyards (Ingledew \& Kunkee, 1985; Backhus et al., 2001). In many cases where stuck fermentations have been reported, both killer and wine yeasts were strains of $S$. cerevisiae. Given that killer yeasts are generally resilient to their own toxin, and utilise 


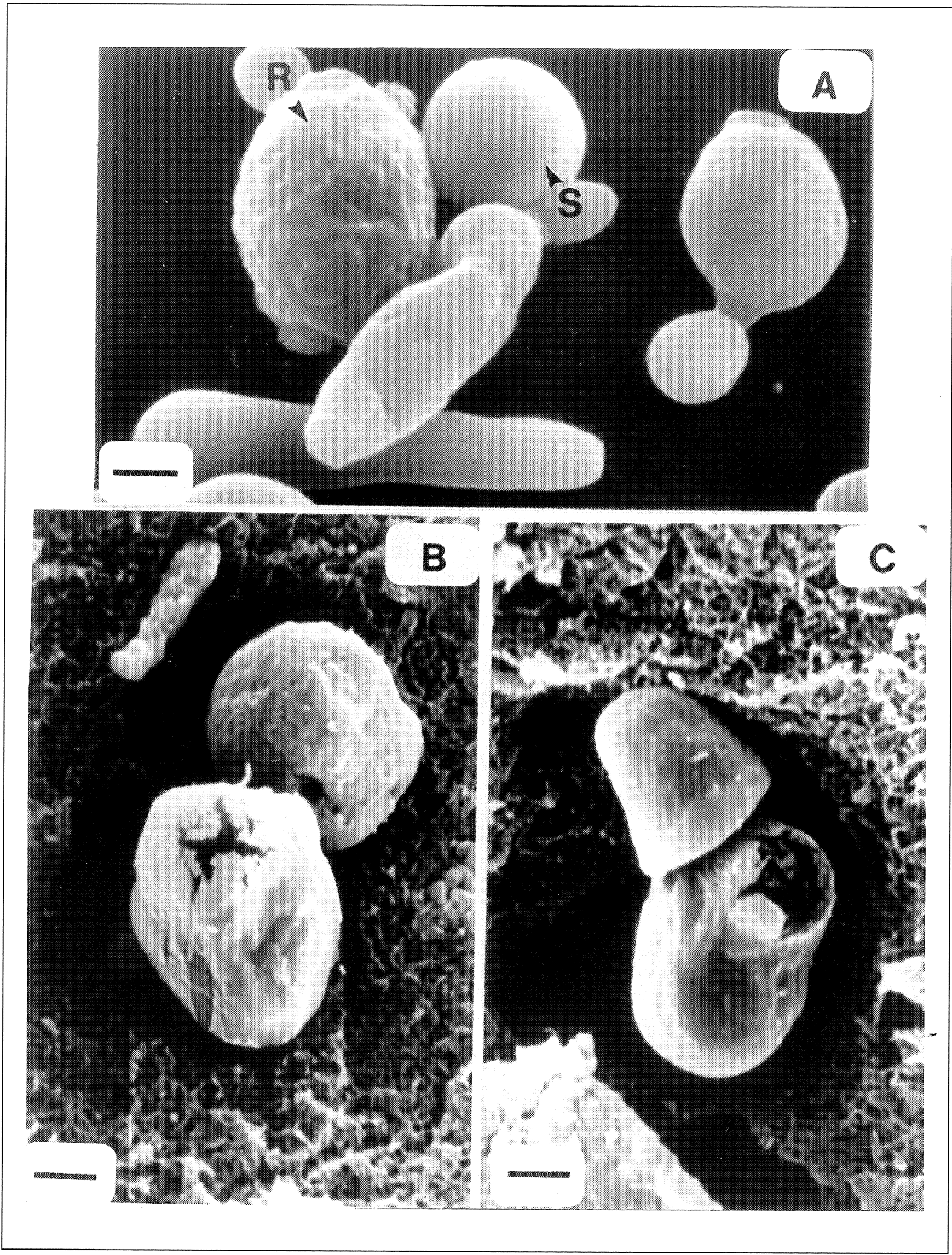

FIGURE 4

SEM images of yeast challenge experiments revealing smooth (S) undamaged cells, toxin-damaged rippled (R) cells (Panel A) and cells showing cracks (Panel B) and pores (Panel C). Bar scales represent $1 \mu \mathrm{m}$ (Vadasz et al., 2000a). 


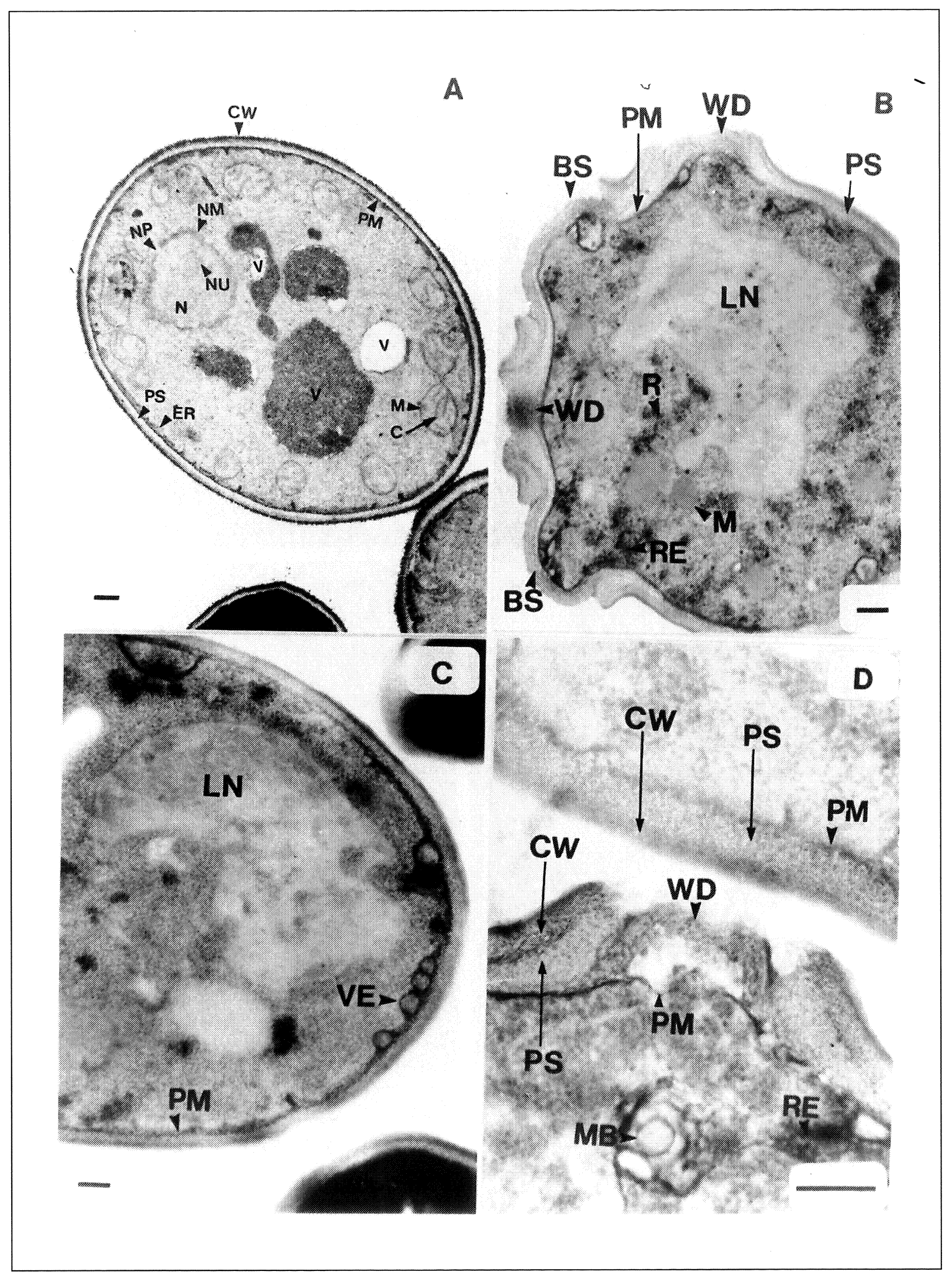

FIGURE 5

TEM images typical of undamaged (A) and toxin-damaged yeast cells (B) showing plasma membrane-associated vesicles (C) and disruption of the cell wall (D). Abbreviations: BS, bud scar; C, cristae; CW, cell wall; ER, endoplasmic reticulum; LN, lobular nucleus; M, mitochondrion; MB, microbody; N, nucleus; NM, nuclear membrane; NP, nuclearpore; NU, nucleolus; PM, plasma membrane; PS, periplasmic space; RE, rough endoplasmic reticulum; R, ribosomes; V, vacuole; VE, plasma membrane-associated vesicle; WD, cell wall damage. Bars represent $200 \mathrm{~nm}$ (Vadasz et al., 2000c). 


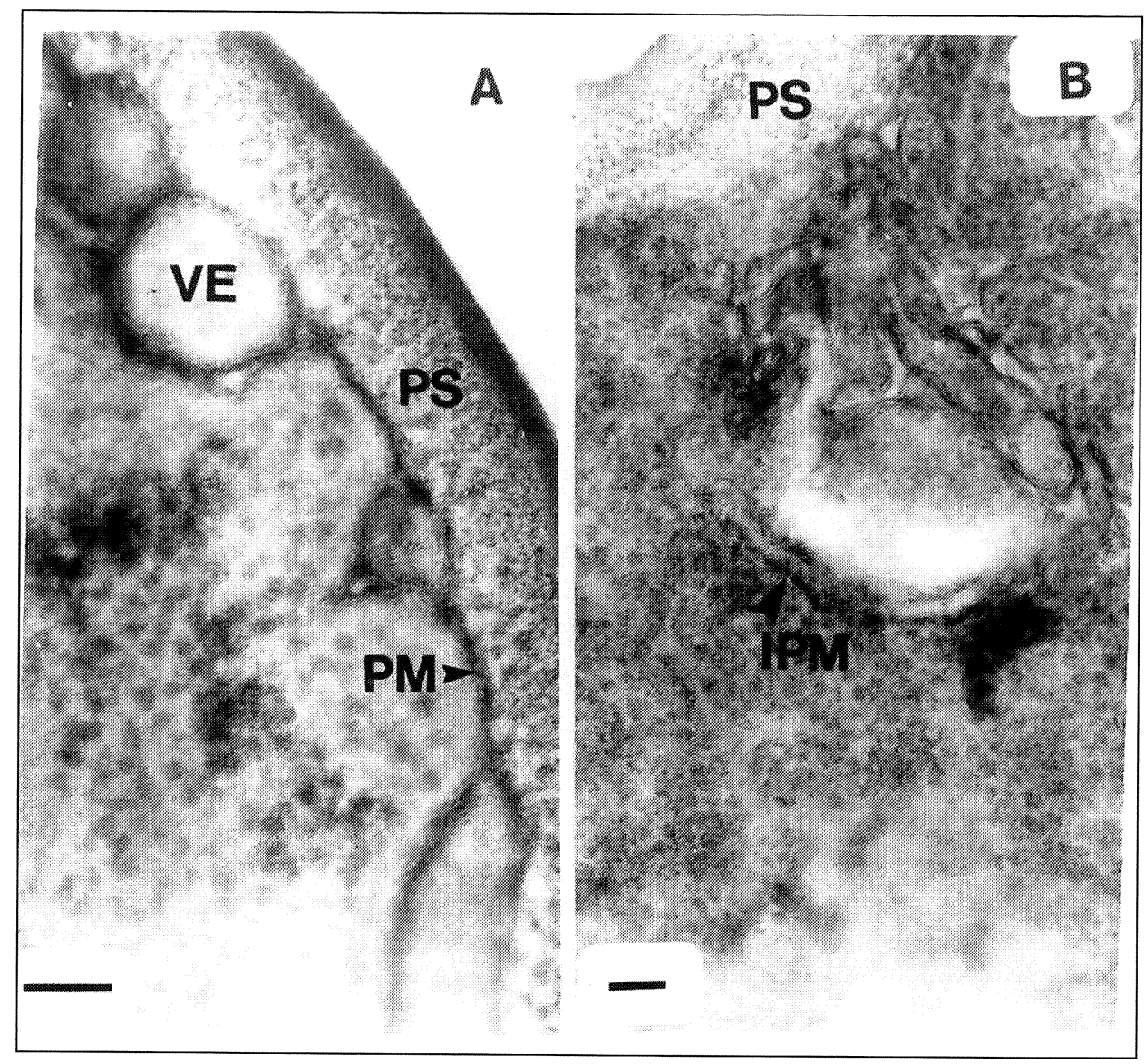

FIGURE 6

Plasma membrane-associated vesicle (VE) (A), possibly due to invagination (B) or fusion of golgi cisternae - originated vesicle. Abbreviations: PM, plasma membrane; PS, periplasmic space; IPM, invagination of plasma membrane or fusion of golgi cisternae - originated vesicle (Vadasz et al., 2000a).

similar substrates as the desired wine yeasts, one questions the reason for a stuck fermentation. Dominant killer yeasts should be able to complete such fermentations; however, the flavour of the end product is less predictable. Indeed, Franken et al. (1998) demonstrated such trends when logarithmic phase cells of the mesophilic wine yeast, $S$. cerevisiae CSIR Y217 K-R', were challenged by strain $\mathrm{T} 206 \mathrm{~K}^{+} \mathrm{R}^{+}$in a nitrogen-enriched Hanepoot grape juice medium at a killer:sensitive cell ratio of 1:100. Over $65 \%$ of the cell population was killed in $72 \mathrm{~h}$; however, the killer yeast was able to produce similar yields of ethanol, acetic acid and glycerol compared with control (single) cultures. The fermentations were neither stuck nor protracted as the rate of production of these metabolites compared favourably with those of the unchallenged control experiments. Vadasz et al. (2000b) demonstrated similar fermentation trends using less-enriched $5 \%$ grape juice medium; however, the percentage of dead cells in killer-challenged cultures was barely 10 over $72 \mathrm{~h}$. It is likely that nutrient depletion might influence lower levels of toxin production by strain T206, but this requires further investigation. Vadasz et al. (2000b) also showed that nutrient depletion induced mesophilic wine yeasts to produce mucoid secretions (Fig. 7) which could potentially mask the $\mathrm{K}_{2}$ killer toxin receptor, thereby suppressing the killer effect.
In $S$. cerevisiae it is evident that the depletion of nutrients, such as grape sugar and nitrogen in growth media, can potentially activate flocculation or pseudohyphae formation through induction of the structural flocculation genes FLO1, FLO5 and FLO11/MUC1 (Lambrechts et al., 1996; Gagiano et al., 1999). In nutrient-limiting agar media it is presumed that yeasts anchor to such media with mucin-like proteins promoting adhesion or aggregation of cells, while pseudohyphae forage for the nutrients. More recently Reynolds \& Fink (2001) have reported pseudohyphae formation and biofilm or mat growth patterns by $S$. cerevisiae FLO11 strains on $0.3 \%$ semi-solid agar medium containing low glucose concentrations. In their study $S$. cerevisiae $\Delta$ floll strains were recalcitrant to producing pseudohyphae and mats or biofilms under such conditions.

We have recently demonstrated in our laboratory that the killer effect of strain T206 on mesophilic wine yeasts can be strongly inhibited in a nitrogen-enriched Hanepoot grape juice medium when a supplement of either 1, 50 or $100 \mathrm{ppm}$ bovine submaxillary gland mucin is added to the medium (Fig. 8). This result supports the assertion made earlier that mucin might mask the cognate $\mathrm{K}_{2}$ killer toxin receptor; however, the effect of both nutrient status and mucin on the toxin production requires further investigation. The complexation and inactivation of free, secreted killer 


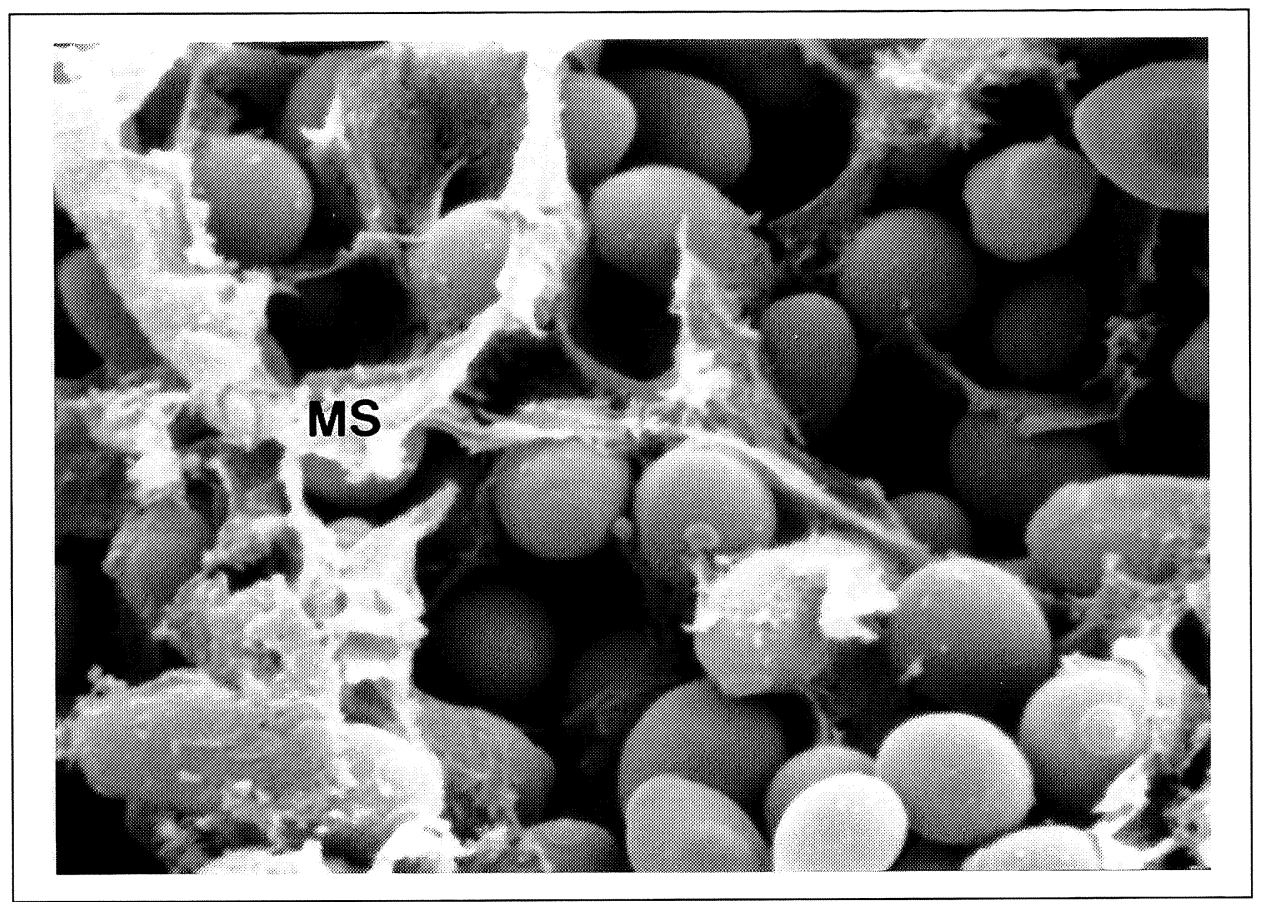

FIGURE 7

SEM image of the intermittent distribution of mucoid sheaths (ms) in liquid culture (Vadasz et al., 2000b).
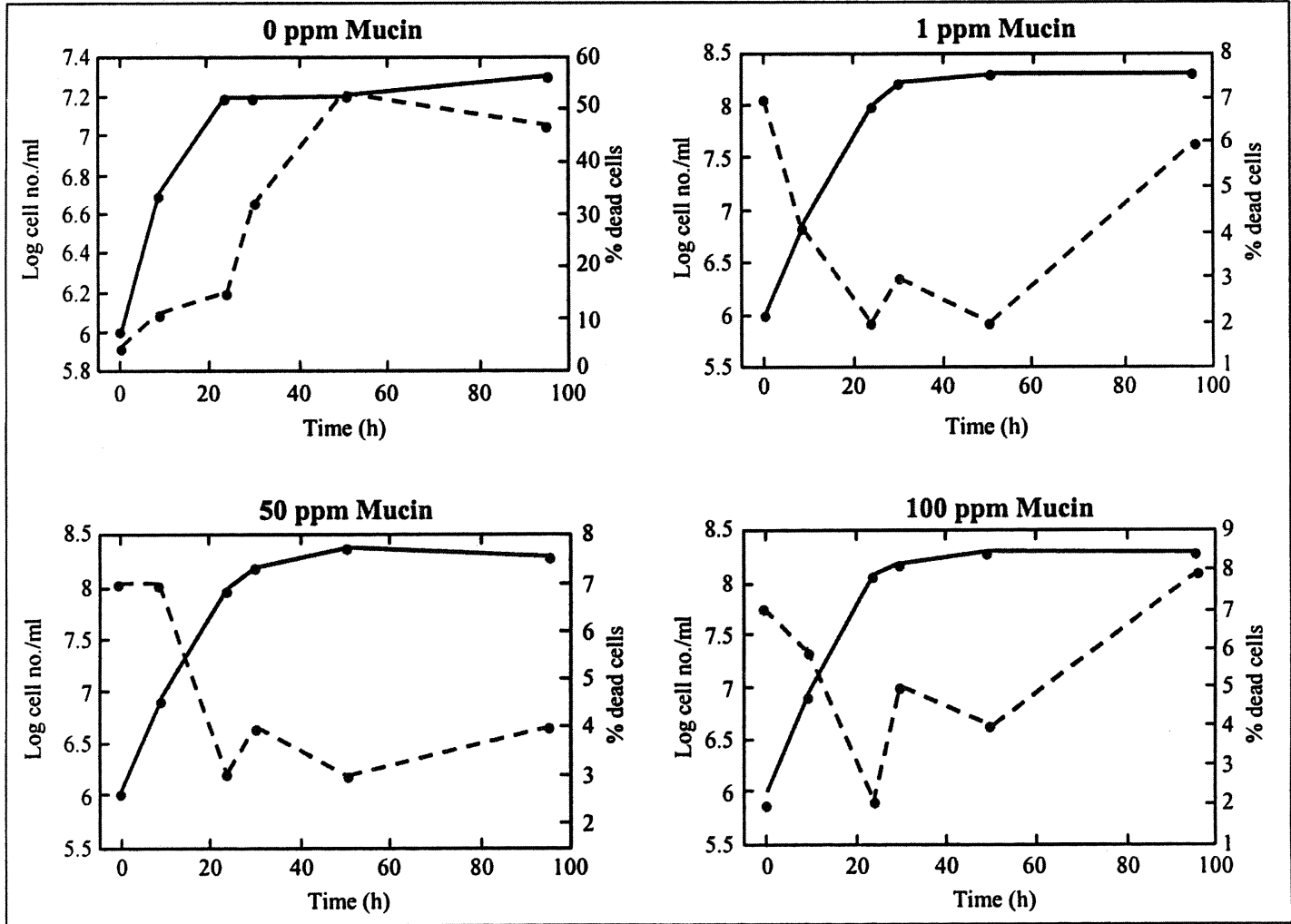

\section{FIGURE 8}

The effect of mucin supplementation on the killer activity of $S$. cerevisiae T206 against $S$. cerevisiae VIN7. The killer yeast was introduced at $9 \mathrm{~h}$ of growth of the sensitive yeast at a killer: sensitive cell ratio of 1:100 and grown in nitrogen-enriched Hanepoot grape juice medium as described (Franken et al., 1998). The log cells $/ \mathrm{mL}$ is indicated by the solid line and the percentage of dead cells by the dotted line. 
toxin by mucin, prior to interaction with its cognate receptor, is another possibility.

Clearly, we have established that a single yeast strain (S. cerevisiae T206) has the potential to interfere with the wine fermentation process as demonstrated in simulated challenge experiments. Further research is therefore required on the $S$. cerevisiae $\mathrm{T} 206 \mathrm{~K}_{2}$ toxin as its interaction with sensitive yeast cells in grape juice mixtures is far from understood.

\section{LITERATURE CITED}

Ahmed, A., Sesti, F., Ilan, N., Shih, T.M., Sturley, S.L. \& Goldstein, S.A.N., 1999 A molecular target for viral killer toxin: TOK1 potassium channels. Cell 99, 283 291.

Backhus, L.E., DeRisi, J., Brown, P.O. \& Bisson, L.F., 2001. Functional genomic analysis of a commercial wine strain of Saccharomyces cerevisiae under differing nitrogen conditions. FEMS Yeast Res. 1, 111-125.

Benda, I., 1985. Hefen in der Kellerwirtschaft - Untersuchungen über sogenannte killerhefen beider Mostgärung. Dtsch. Weinbau 40, 1166-1171.

Bidenne, C., Blondin, B., Dequin, S. \& Vezinhet, F., 1992. Analysis of the chromosome DNA polymorphism of wine strains of Saccharomyces cerevisiae. Curr Genet. 22, 1-7.

Bostian, D.J. \& Tipper, K.A., 1984. Double-stranded ribonucleic acid killer systems in yeast. Microbiol. Rev. 48, 125-156.

Bussey, H., 1991. K 1 killer toxin, a pore-forming protein from yeast. Mol. Microbiol. 5, 2339-2343.

Carle, G.F. \& Olsen, M.V., 1985. An electrophoretic karyotype for yeast. Proc. Natl. Acad. Sci. USA 82, 3756-3760.

Carrau, F.M., Neirotti, E. \& Gioia, O., 1993. Stuck wine fermentations: Effect of killer/sensitive yeast interactions. J. Ferment. Bioeng. 76, 67-69.

Extremera, A.L., Martin, I. \& Montoya, E., 1982. A new killer toxin produced by Saccharomyces cerevisiae. Curr. Genet. 5, 17-19.

Fink, G.R. \& Styles, C.A., 1972. Curing of a killer factor in Saccharomyces cerevisiae. Proc. Nat. Acad. Sci. USA 69, 2846-2849.

Franken, D.B., Ariatti, M., Pretorius, I.S. \& Gupthar, A.S., 1998. Genetic and fermentation properties of the $\mathrm{K}_{2}$ killer yeast, Saccharomyces cerevisiae $\mathrm{T} 206$. Antonie van Leeuwenhoek 73, 263-269.

Gagiano, M., Van Dyk, D., Bauer, F.F., Lambrechts, M.G. \& Pretorius, I.S., 1999 Msn1p/Mss10p, Mss11p and Muc1p are part of a signal transduction pathway downstream of Mep2p regulating invasive growth and pseudohyphal differentiation in Saccharomyces cerevisiae. Mol. Microbiol. 31, 103-116.

Heard, G.M. \& Fleet, G.H., 1987. Occurrence and growth of killer yeasts during wine fermentation. Appl. Environ. Microbiol. 53, 2171-2174.

Hutchins, K. \& Bussey, H., 1983. Cell wall receptor for yeast killer toxin Involvement of $(1 \rightarrow 6) \beta-D$ glucan. J. Bacteriol. 154, 161-169.

Ingledew, W.M. \& Kunkee, R.E., 1985. Factors influencing sluggish fermentations of grape juice. Am. J. Enol. Vitic. 36, 65-70.

Jacobs, C.J. \& Van Vuuren, H.J.J., 1991. Effects of different killer yeasts on wine fermentations. Am. J. Enol. Vitic. 42, 295-300.
Kaback, D.B., 1989. Meiotic segregation of circular plasmid-minichromosomes from intact chromosomes in Saccharomyces cerevisiae. Curr. Genet. 15, 385-392.

Lambrechts, M.G., Bauer, F.F., Marmur, J. \& Pretorius, I.S., 1996. Muc1, a mucin-like protein that is regulated by MSS10 is critical for pseudohyphal differentiation in yeast. Proc. Natl. Acad. Sci. USA 93, 8419-8424.

Longo, E., Velázquez, J.B., Cansado, J., Cao, P. \& Villa, T.G., 1990. Role of killer effect in fermentations conducted by mixed cultures of Saccharomyces cerevisiae. FEMS Microbiol. Lett. 71, 331-336.

Longo, E. \& Vezinhet, F., 1993. Chromosomal rearrangement during vegetative growth of a wild strain of Saccharomyces cerevisiae. Appl. Environ. Microbiol. 59, 322-326

Martinac, B., Zhu, H., Kubalski, A., Zhou, X.L., Culbertson, M., Bussey, H. \& Kung, C., 1990. Yeast $K_{1}$ killer toxin forms ion channels in sensitive yeast spheroplasts and in artificial liposomes. Proc. Natl. Acad. Sci. USA 87, 6228-6232.

Pfeiffer, P. \& Radler, F., 1982. Purification and characterisation of extracellular and intracellular killer toxin of Saccharomyces cerevisiae strain 28. J. Gen. Microbiol. 128, 2699-2706.

Pfeiffer, P. \& Radler, F., 1984. Comparison of the killer toxin of several yeasts and the purification of a toxin of type $\mathrm{K}_{2}$. Arch. Microbiol. 137, 357-361.

Radler, F. \& Knoll, C., 1988. Die Bildung von Killertoxin und die Beeinflussung der Gärung durch Apiculatus - Hefen. Vitis 27, 111-132.

Reynolds, T.B. \& Fink, G.R., 2001. Baker's yeast, a model for fungal biofilm formation. Science 291, 878-881.

Rogers, D. \& Bevan, E.A., 1978. Group classification of killer yeasts based on cross-reactions between strains of different species and origin. J. Gen. Microbiol. 105, 199-202.

Sommer, S.S. \& Wickner, R.B., 1984. Double-stranded RNAs that encode killer toxin in Saccharomyces cerevisiae: unstable size of M double-stranded RNA and inhibition of $\mathrm{M}_{2}$ replication by $\mathrm{M}_{1}$. Mol. Cell. Biol. 4, 1747-1753.

Starmer, W.T., Ganter, P.F., Aberdeen, V., Lachance, M.-A. \& Phaff, H.F., 1987. The ecological role of killer yeasts in natural communities of yeast. Can. J. Microbiol. 33, 783-796.

Vadasz, A.S., 2000. Microscale vinifications challenged by a $\mathrm{K}_{2}$ killer yeast. B.Sc. Hons. Thesis, University of Durban-Westville.

Vadasz, A.S., Jagganath, D.B., Pretorius, I.S. \& Gupthar, A.S., 2000a. Electron microscopy of the $\mathrm{K}_{2}$ killer effect of Saccharomyces cerevisiae T206 on a mesophilic wine yeast. Antonie van Leeuwenhoek 78, 117-122.

Vadasz, A.S., Jagganath, D.B., Pretorius, I.S. \& Gupthar, A.S., 2000b. Mucoid secretions by the wine yeast, Saccharomyces cerevisiae VIN7. Proc. Microscopy Soc. of South Africa 30, 34.

Van der Westhuizen, T.J. \& Pretorius, I.S., 1992. The value of electrophoretic fingerprinting and karyotyping in wine yeast breeding programmes. Antonie van Leeuwenhoek 61, 249-257.

Van Vuuren, H.J.J. \& Jacobs, C.J., 1992. Killer yeasts in the wine industry: A review. Am. J. Enol. Vitic. 43, 199-128.

Van Vuuren, H.J.J. \& Wingfield, B.D., 1986. Killer yeasts - cause of stuck fermentations in a wine cellar. S. Afri. J. Enol. Vitic. 7, 113-118.

Wingfield, B.D., Southgate, V.J., Pretorius, I.S. \& Van Vuuren, H.J.J., 1990. A K 2 neutral Saccharomyces cerevisiae strain contains a variant $\mathrm{K}_{2} \mathrm{M}$ genome. Yeast 6 , $159-169$.

Young, T.W. \& Yagiu, M., 1978. A comparison of the killer character in different yeasts and its classification. Antonie van Leeuwenhoek 44, 59-77. 